\title{
Downregulation of MicroRNA-330 Correlates with the Radiation Sensitivity and Prognosis of Patients with Brain Metastasis from Lung Cancer
}

\author{
Li-Peng Jiang $^{\mathrm{a}}$ Zhi-Tu Zhu ${ }^{\mathrm{b}}$ Yue Zhang ${ }^{c}$ Chun-Yan Hec \\ aDepartment of Radiation Oncology, ${ }^{b}$ Department of Oncology, The First Affiliated Hospital of Jinzhou \\ Medical University, 'Department of Prosthodontics, The Second Affiliated Hospital of Jinzhou Medical \\ University, Jinzhou, China
}

\section{Key Words}

MicroRNA-330 $\bullet$ Lung cancer with brain metastasis $\bullet$ Radiation therapy $\bullet$ Sensitivity $\bullet$ Prognosis - Follow-up

\begin{abstract}
Background: The present study sought to explore the role of microRNA-330 (miR-330) in predicting the radiation response and prognosis of patients with brain metastasis (BM) from lung cancer (LC). Methods: Patients with BM from LC were identified and classified into radiation-sensitive and radiation-resistant groups according to the overall survival rate, local and distant recurrence rate after conventional whole-brain radiation therapy. Quantitative realtime polymerase chain reaction (qRT-PCR) was used to detect miR-330 expression in serum. Receiver operating characteristic (ROC) curves were used to evaluate the prognostic value of miR-330 for the radiation sensitivity of brain metastasis from LC. Related clinical factors for radiation sensitivity were assessed by logistic regression analysis, and a survival analysis was conducted using COX regression and the Kaplan-Meier method. Results: MiR-330 exhibited lower expression in the radiation-sensitive group than in the radiation-resistant group. The area under the ROC curve of miR-330 for predicting radiation sensitivity was 0.898 (optimal cut-off value, 0.815 ), with a sensitivity of $71.7 \%$ and a specificity of $90.1 \%$. After radiation therapy, patients with low miR-330 expression, compared to patients with high miR-330 expression, displayed a lower survival rate and a median survival time. MiR-330 expression was correlated with extracranial metastasis, maximum BM diameter, tumor-node-metastasis (TNM) stage and node $(\mathrm{N})$ stage. Logistic regression and COX regression analyses revealed that extracranial metastasis, TNM stage, $\mathrm{N}$ stage and miR-330 expression were factors that influenced both radiation sensitivity and individual prognostic factors in patients with BM from LC. Conclusions: These findings indicate that the downregulation of miR-330 correlates with radiation sensitivity and poor prognosis in patients with BM from LC.




\section{Introduction}

Lung cancer (LC), including small-cell lung cancer (SCLC) and non-small-cell lung cancer (NSCLC), is the most common cause of cancer deaths worldwide [1-3]. Over 80\% of LCs are NSCLC, which confers a very low 5-year survival rate [4]. Currently, radiation therapy has been a common treatment for patients with LC [5-7]. Major causes contributing to poor outcomes in patients with LC include innate or acquired resistance to radiotherapy and high metastatic potential $[8,9]$. Invasion and metastasis of cancer cells are critical factors that influence the long-term survival of LC and characterized by the capability to invade to adjacent area, extravagate into lymphatic and blood vessels and colonize into a distance environment [10]. Brain metastasis (BM) is one of the direst complications of LC [11] and is a crucial prognostic factor for LC [12]. BM can cause significant cognitive, neurologic and emotional difficulties and can negatively impact patient survival [13], with a median overall survival of 4.5 months for patients receiving standard whole-brain radiation therapy after they were diagnosed with BM in NSCLC [14]. The accurate assessment of BM plays a critical role in LC management, and an early diagnosis can result in a better survival [15]. Previous efforts to characterize patients with LC who will develop BM have been disappointing [13]; thus, we resort to molecular mechanisms in order to provide a more accurate evaluation of patients with BM from LC. MicroRNAs (miRNAs) are non-coding RNAs of approximately 1824 nucleotides that can bind to the sequences of target mRNAs in the 3 '-untranslated region (3'-UTR) and modulate gene expression at the post-transcriptional level $[16,17]$, therefore affecting a wide variety of biological processes, including proliferation, differentiation as well as and apoptosis. Thus, these miRNAs are associated with a diverse array of human diseases, including cancer [18-20]. The altered expression of miRNAs has been commonly found in LC $[21,22]$, and accumulatively been evidenced to involve in carcinogenesis and tumor progression in LC [23-25]. As a member of the miRNA family, microRNA-330 (miR330 ) has two subsidiary strands, miR-330-3p and miR-330-5p [26]. Serum miR-330 is reported to function as a tumor suppressor in prostate cancer [27, 28]. Evidence also shows that the elevated expression of miR-330 can suppress the proliferation of colorectal cancer cells in vivo [29]. However, the functions and molecular mechanisms concerning miR-330 in the regulation of LC are currently unknown. Moreover, serum miRNAs can function as novel biomarkers to predict the response to radiotherapy and the prognosis clinically [30, 31]. By using quantitative real-time polymerase chain reaction (qRT-PCR) to detect miR-330 expression in serum, our study aimed to investigate the role of miR-330 in predicting the radiation sensitivity and prognosis of patients with BM from LC.

\section{Materials and Methods}

Study Subjects

A total of 258 patients with LC and brain metastasis diagnosed at the Second Affiliated Hospital of Jinzhou Medical University from January 2010 to December 2015 were identified. All subjects (153 males and 105 females) had a median age of 59 years, ranging from 35 to 75 years. The subjects were confirmed based on cytology or histopathology, and brain metastasis was confirmed by surgical pathology or clinical diagnosis, such as physical signs, brain computed tomography, clinical symptoms and nuclear magnetic resonance. The inclusion criteria were patients with complete medical records, diagnosis of the primary tumor as brain metastasis, patients receiving no surgical treatment but whole-brain radiation therapy, no acute hemorrhage or abnormal routine blood work, at least 1 assessable tumor lesion or measurable intracranial metastatic lesion by magnetic resonance imaging and a Karnofsky Performance Scale (KPS) score no less than 60 points [32]. Exclusion criteria were patients with mental abnormalities; patients with severe dysfunction in the heart, liver, kidney and other organs; and patients with other tumor lesions except for brain metastatic lesions and primary tumors. The general information and clinical records of all subjects are listed in Table 1. Informed consent was obtained from all subjects, and the investigation was approved by the ethical committee of the Second Affiliated Hospital of Jinzhou Medical University.

\section{KARGER}


$\begin{array}{ll}\begin{array}{l}\text { Whole-Brain } \\ \text { Therapy }\end{array} & \text { Radiation } \\ \text { Table 1. General information and clinical characteristics of patients. } \\ \text { BM, brain metastasis; TNM, tumor-node-metastasis; N, Node }\end{array}$

All subjects received

conventional whole-brain radiation therapy with a NucletronSimulix simulator (Nucletron B.V., Veenendaal, The Netherlands) [33]. The patients put in the supine position, with the head fixed by a U-shape thermoplastic mask and supported by a pillow. The front and back of the head and the upper bound were exposed. The lower bound was along the supraorbital, orbital, front and bottom of the sphenoid sinus; the top of the nasopharynx; and the inferior border of the $\mathrm{C} 1$ spine. The radiation therapy dose was 30 Gy (3 Gy $\times 10$ fractions) for 5 weeks. The patients were classified into the radiation-sensitive group and the radiation-resistant group based on the overall survival rate and the distant and local recurrence rate [34].

Quantitative Real-Time Polymerase Chain Reaction ( $q R T-P C R$ )

\begin{tabular}{lll}
\hline Characteristics & Category & Case \\
\hline \multirow{2}{*}{ Gender } & Male & 153 \\
& Female & 105 \\
Age (Year) & $\leq 60$ & 146 \\
& $>60$ & 112 \\
Pathological type & Adenocarcinoma & 149 \\
& Squamous cell carcinoma & 61 \\
Extracranial metastasis & Other types & 48 \\
\multirow{4}{*}{ Number of brain metastatic lesions } & Without & 142 \\
Maximum diameter of BM $(\mathrm{cm})$ & With & 116 \\
& $\leq 2$ & 94 \\
TNM stage & $>2$ & 164 \\
& $\mathrm{~T} 1$ & 95 \\
N stage & $\mathrm{T} 2$ & 163 \\
& $\mathrm{~T} 3$ & 142 \\
& $\mathrm{~N} 0$ & 35 \\
& $\mathrm{~N} 1$ & 29 \\
& $\mathrm{~N} 2$ & 58 \\
& & 171 \\
\hline
\end{tabular}

Table 2. Primer sequences of the target genes. F, Forward; R, Reverse; miR-330, microRNA-330

\begin{tabular}{ll}
\hline Target gene & Primer sequence \\
\hline \multirow{2}{*}{ miR-330 } & F: 5'-GGGCTCGAGCCACTCACCCACACTGAAGA-3' \\
& R: 5'-GGGGCGGCCGCGTTTCTCCCTCTGCTTGACG-3' \\
\multirow{2}{*}{ U6 } & F: 5'-CGCTTCGGCAGCACATATACTA-3' \\
\hline
\end{tabular}

Venous blood $(10 \mathrm{~mL})$ was obtained from fasting patients in the morning before radiation therapy, and serum was collected after centrifugation. Total RNA was extracted using a Trizol total RNA Extraction Kit (Shanghai Sangon Biological Engineering Technology \& Services Co., Ltd., Shanghai, China) and was then reverse transcribed into complementary DNA (cDNA). Total RNA $(1 \mu \mathrm{L}), 50 \mu \mathrm{mol} / \mathrm{L}$ Oligo-dT Prime $(0.5$ $\mu \mathrm{L}), 5 \times$ PrimeScript TM Buffer $(2 \mu \mathrm{L})$, PrimeScriptTM RT Enzyme $(0.5 \mu \mathrm{L})$ and $50 \mu \mathrm{mol} / \mathrm{L}$ Random 6 -mers $(0.5 \mu \mathrm{L})$ were obtained with the addition of RNase-free $\mathrm{dH}_{2} \mathrm{O}$ to a total volume of $20 \mu \mathrm{L}$. The solution was mixed and reacted at $37^{\circ} \mathrm{C}$ for $15 \mathrm{~min}$ and then at $83^{\circ} \mathrm{C}$ for $3 \mathrm{~s}$. The reaction was terminated by cooling on the ice, followed by the addition of sterile water $(80 \mu \mathrm{L})$ and storage at $-20^{\circ} \mathrm{C}$. Based on the cDNA template, miR-330 expression was detected by a fluorescence quantitative PCR reaction according to the fluorescence quantitative PCR kit (Takara Biotechnology Ltd., Dalian, China). Primer sequences are shown in Table 2. Each group had 3 duplicate wells. The reaction contained Synergy Brands (SYBR) Premix ExTaqTM $(2 \times$ ) $(10 \mu \mathrm{L}), 10 \mu \mathrm{mol} / \mathrm{L}$ PCR Primer $(0.4 \mu \mathrm{L})$, ROX Reference Dye II $(50 \times)(0.4 \mu \mathrm{L})$ and cDNA template $(2.0$ $\mu \mathrm{L})$, with the addition of $\mathrm{dH}_{2} \mathrm{O}(6.8 \mu \mathrm{L})$ to a total volume of $20 \mu \mathrm{L}$. A LightCycler 480 system was used for a fluorescence quantitative PCR reaction with the following reaction conditions: pre-denaturation at $95^{\circ} \mathrm{C}$ for $10 \mathrm{~min}$, denaturation at $94^{\circ} \mathrm{C}$ for $15 \mathrm{~s}$, annealing at $60^{\circ} \mathrm{C}$ for $1 \mathrm{~min}$, and extension at $72^{\circ} \mathrm{C}$ for $1 \mathrm{~min}$, with 40 cycles. With $\mathrm{U} 6$ as an internal reference, the relative mRNA expression was calculated by the $2^{-\triangle \Delta C \mathrm{CT}}$ method [35].

Follow-up

All patients received follow-up through outpatient visits and by telephone through June 2016, with no cases lost to follow-up. The survival time was assessed monthly, and the diagnosis date was set as the beginning of follow-up. The period from the diagnosis date to death caused by brain metastasis or recurrence was considered the survival time. The totally lost cases, the non-tumor derived deaths and the living patients at the end of follow-up were counted as censored data in conformity with the requirements of statistics. 


\section{Cellular Physiology Cell Physiol Biochem 2017;42:2220-2229 \begin{tabular}{ll|l} 
and Biochemistry Published onlIne: August 16, 2017 & $\begin{array}{l}\text { (C) } 2017 \text { The Author(s). Published by S. Karger AG, Basel } \\
\text { www.karger.com/cpb }\end{array}$
\end{tabular}}

\section{Statistical Analysis}

All data were processed with the Statistical Package for the Social Sciences (SPSS) version 21.0 (SPSS Inc., Chicago, IL, USA). Measurement data are displayed as the mean \pm standard deviation (SD). Comparisons between two groups were analyzed by $t$ test. Categorical data were detected by the chi-square test, and the rank sum test was used for ranked data. Receiver operating characteristic (ROC) curves were used to evaluate the prognostic value of miR-330 for the radiation sensitivity of brain metastasis from LC. Related clinical factors for radiation sensitivity were assessed by logistic regression analysis, and survival analysis was assessed by COX regression and Kaplan-Meier method. $P<0.05$ was considered statistically significant.

\section{Results}

Clinical Characteristics of the Patients in the Radiation-Sensitive and-Resistant Groups

There were 131 cases in the radiation-sensitive group, including 75 males and 56 females, and 127 cases in the radiation-resistant group, including 78 males and 49 females. Patients in both groups exhibited no significant differences regarding gender, age, pathological type, extracranial metastasis, brain metastasis number, brain metastasis maximum diameter, tumor-node-metastasis (TNM) stage and node $(\mathrm{N})$ stage (all $P>0.05$ ) (Table 3 ).

The miR-330 Expression in Serum in the Radiation-Sensitive and Radiation-Resistant Groups

The results of qRT-PCR indicated that the miR-330 expression in the serum was reduced in the radiation-sensitive group compared to that in the radiation-resistant group $(P<0.05$, Fig. 1A). ROC curves were applied to evaluate the prognostic value of miR-330 expression for radiation sensitivity. The area under the curve was 0.898 , the $95 \% \mathrm{CI}$ was $0.862 \sim 0.934$, the optimal cut-off value was 0.815 , the sensitivity was $71.7 \%$, and the specificity was $90.1 \%$ (Fig. 1B).

Correlation between miR-330 Expression and Clinical Characteristics of Patients with BM from $L C$

With the optimal cut-off value of 0.815 as a standard for radiation sensitivity, 104 patients had high expression of miR-330 ( $\geq 0.815$ ), and 154 patients had low expression of miR-330 (<0.815). The findings implied that miR-330 expression presented no correlation with gender, age, and pathological type, as well as the number and maximum diameter of brain metastases (all $P>0.05$ ), while miR-330 expression was correlated with extracranial

Table 3. Clinical characteristics of the patients in the radiation-sensitive and radiation-resistant groups. BM, brain metastasis; TNM, tumor-node-metastasis; N, node

\begin{tabular}{|c|c|c|c|c|}
\hline Characteristics & Category & $\begin{array}{c}\text { Radiation-sensitive } \\
\text { group } \\
(\mathrm{n}=131) \\
\end{array}$ & $\begin{array}{c}\text { Radiation-resistant } \\
\text { group } \\
(\mathrm{n}=127) \\
\end{array}$ & $P$ \\
\hline \multirow{2}{*}{ Gender } & Male & $75(49.02)$ & $78(50.98)$ & \multirow{2}{*}{0.528} \\
\hline & Female & $56(53.33)$ & $49(46.67)$ & \\
\hline \multirow{3}{*}{ Age (Year) } & $\leq 60$ & $73(50.00)$ & $73(50.00)$ & \multirow{3}{*}{0.611} \\
\hline & $>60$ & $58(51.79)$ & $54(48.21)$ & \\
\hline & Adenocarcinoma & $78(52.35)$ & $71(47.65)$ & \\
\hline \multirow[t]{2}{*}{ Pathological type } & $\begin{array}{l}\text { Squamous cell } \\
\text { carcinoma }\end{array}$ & $27(44.26)$ & $34(55.74)$ & \multirow[t]{2}{*}{0.496} \\
\hline & Other types & $26(54.17)$ & $22(45.83)$ & \\
\hline \multirow{2}{*}{ Extracranial metastasis } & Without & $80(56.33)$ & $62(43.67)$ & \multirow{2}{*}{0.060} \\
\hline & With & $51(43.97)$ & $65(56.03)$ & \\
\hline \multirow{2}{*}{$\begin{array}{l}\text { Number of brain metastatic } \\
\text { lesions }\end{array}$} & 1 & $46(48.94)$ & $48(51.06)$ & \multirow{2}{*}{0.699} \\
\hline & $\geq 2$ & 85 (51.83) & 79 [48.17) & \\
\hline \multirow{3}{*}{ Maximum diameter of BM } & $\leq 2 \mathrm{~cm}$ & $50(52.63)$ & $45(47.37)$ & \multirow{3}{*}{0.699} \\
\hline & $>2 \mathrm{~cm}$ & $81(49.69)$ & $82(50.31)$ & \\
\hline & T1 & $76(53.52)$ & $66[46.48)$ & \\
\hline \multirow[t]{3}{*}{ TNM stage } & $\mathrm{T} 2$ & $45(52.94)$ & $40(47.06)$ & \multirow[t]{3}{*}{0.090} \\
\hline & $\mathrm{T} 3$ & $10(32.26)$ & $21(67.74)$ & \\
\hline & No & $14(48.28)$ & $15(51.72)$ & \\
\hline \multirow[t]{2}{*}{ N stage } & N1 & $24(41.38)$ & $34(58.62)$ & \multirow[t]{2}{*}{0.222} \\
\hline & $\mathrm{N} 2$ & $93(54.39)$ & $78(45.61)$ & \\
\hline
\end{tabular}




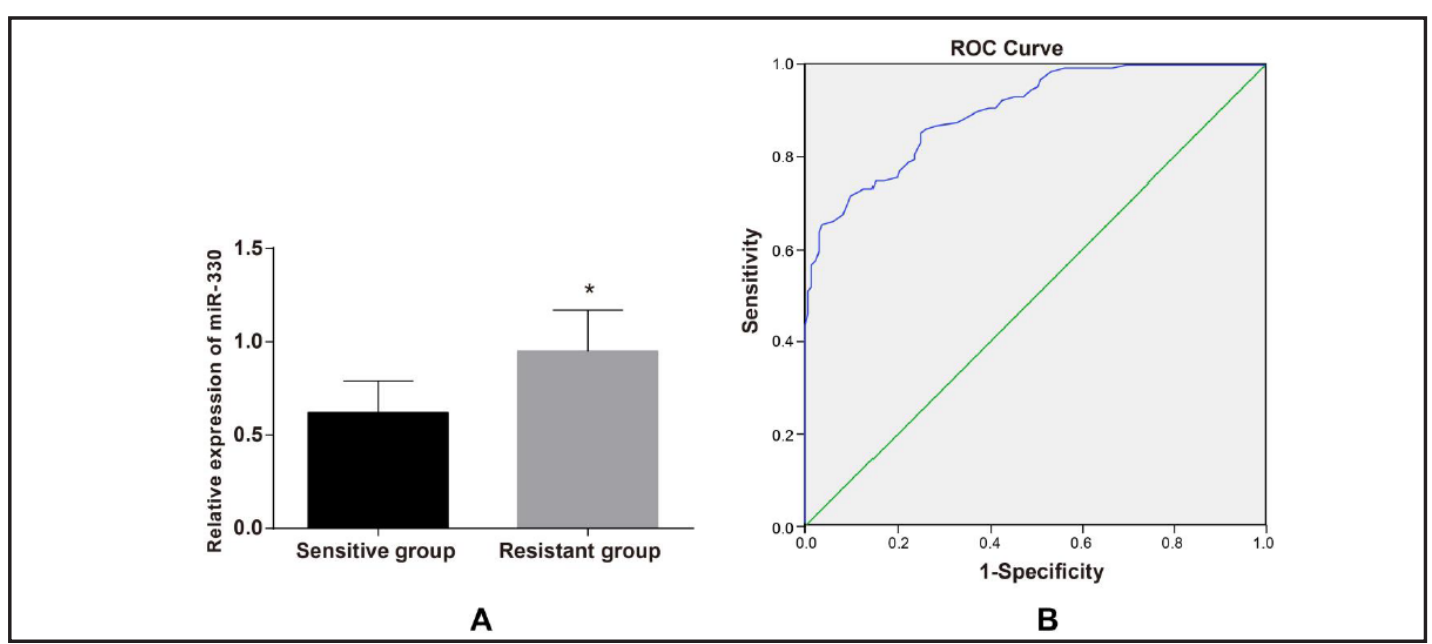

Fig. 1. MiR-330 expression in the serum of the radiation-sensitive and radiation-resistant groups, and the prognostic value for the radiation sensitivity of patients with BM from LC. (A) miR-330 expression in the serum of the radiation-sensitive and radiation-resistant groups; * $P<0.05$ compared with the radiation-sensitive group; (B) ROC curve for miR-330 expression in predicting the radiation sensitivity of patients with BM from LC; miR-330, microRNA-330; LC, lung cancer; ROC, receiver operating characteristic; BM, brain metastasis.

Table 4. Correlation between miR-330 expression and the clinical characteristics of patients with BM from LC. LC, lung cancer; BM, brain metastasis; TNM, tumor-node-metastasis; N, node; miR-330, microRNA-330

\begin{tabular}{|c|c|c|c|c|c|}
\hline \multirow[b]{2}{*}{ Characteristics } & \multirow[b]{2}{*}{ Category } & \multicolumn{4}{|c|}{ miR-330 } \\
\hline & & Case & $\begin{array}{l}\text { Low expression } \\
\qquad(\mathrm{n}=154)\end{array}$ & $\begin{array}{l}\text { High expression } \\
\quad(n=104)\end{array}$ & $P$ \\
\hline \multirow{2}{*}{ Gender } & Male & 153 & $95(62.09)$ & $58(37.91)$ & \multirow{2}{*}{0.368} \\
\hline & Female & 105 & $59(56.19)$ & $46(43.81)$ & \\
\hline \multirow{3}{*}{ Age (Year) } & $\leq 60$ & 146 & $91(62.33)$ & $55(37.67)$ & \multirow{2}{*}{0.371} \\
\hline & $>60$ & 112 & $63(56.25)$ & $49(43.75)$ & \\
\hline & Adenocarcinoma & 149 & $96(64.43)$ & $53(35.57)$ & \multirow{3}{*}{0.164} \\
\hline \multirow[t]{2}{*}{ Pathological type } & Squamous cell carcinoma & 61 & $31(50.82)$ & $30(49.18)$ & \\
\hline & Other types & 48 & $27(56.25)$ & $21(43.75)$ & \\
\hline \multirow{2}{*}{ Extracranial metastasis } & Without & 142 & $95(66.90)$ & $47(33.09)$ & \multirow{2}{*}{0.011} \\
\hline & With & 116 & $59(50.86)$ & $57(49.14)$ & \\
\hline \multirow{2}{*}{ The number of BM } & 1 & 94 & $62(65.96)$ & $32(34.04)$ & \multirow{2}{*}{0.147} \\
\hline & $\geq 2$ & 164 & $92(56.09)$ & $72(43.91)$ & \\
\hline \multirow{3}{*}{ Maximum diameter of BM } & $\leq 2 \mathrm{~cm}$ & 95 & $55(57.89)$ & $40(42.11)$ & \multirow{3}{*}{0.694} \\
\hline & $>2 \mathrm{~cm}$ & 163 & $99(60.74)$ & $64(39.26)$ & \\
\hline & $\mathrm{T} 1$ & 142 & $90(63.38)$ & $52(36.62)$ & \\
\hline \multirow[t]{3}{*}{ TNM stage } & $\mathrm{T} 2$ & 85 & $54(63.53)$ & 31 (36.47) & \multirow[t]{3}{*}{0.004} \\
\hline & T3 & 31 & $10(32.26)$ & $21(67.74)$ & \\
\hline & NO & 29 & $19(65.52)$ & $10(34.48)$ & \\
\hline \multirow[t]{2}{*}{ N stage } & N1 & 58 & $43(75.44)$ & $15(24.56)$ & \multirow[t]{2}{*}{0.019} \\
\hline & N2 & 171 & $92(53.49)$ & $79(46.51)$ & \\
\hline
\end{tabular}

metastasis, TNM stage and $\mathrm{N}$ stage (all $P<0.05$ ). Patients with no extracranial metastasis, high TNM stage and high N stage displayed high miR-330 expression (Table 4).

\section{Logistic Analysis of Factors Influencing the Radiation Sensitivity of Patients with BM from} LC

A logistic regression analysis was performed with the radiation sensitivity of patients as a variable and extracranial metastasis, TNM stage, $\mathrm{N}$ stage and miR-330 expression as invariables. The results indicated that extracranial metastasis, TNM stage, $\mathrm{N}$ stage and miR330 expression were factors that influenced the radiation sensitivity of patients with BM from LC (all $P<0.05$, Table 5).

Correlation between miR-330 Expression and Survival Time of Patients with BM from LC At the $6^{\text {th }}$ month and the $1^{\text {st }}$ year after radiation therapy, the survival rates of patients with low miR-330 expression were $86.36 \%$ and $75.97 \%$, respectively, and the median survival 
Table 5. Logistic regression analysis of the factors that influence the radiation sensitivity of patients with BM from LC. LC, lung cancer; BM, brain metastasis; TNM, tumor-node-metastasis; N, node; miR-330, microRNA-330; SE, standard error; Exp., exponential

\begin{tabular}{lcccccc}
\hline Factor & $\mathrm{B}$ & $\mathrm{SE}$ & Wald & $P$ & Exp. (B) & 95.0\%CI for Exp. (B) \\
\hline Extracranial metastasis & 1.102 & 0.318 & 12.026 & 0.001 & 3.010 & $1.615 \sim 5.612$ \\
TNM stage & 0.461 & 0.231 & 3.980 & 0.046 & 1.585 & $1.008 \sim 2.493$ \\
N stage & 0.409 & 0.208 & 3.858 & 0.049 & 1.505 & $1.001 \sim 2.262$ \\
miR-330 & 1.040 & 0.750 & 13.504 & $<0.001$ & 2.830 & $1.625 \sim 4.928$ \\
\hline
\end{tabular}

Table 6. Multivariate analysis of clinicopathological features and miR-330 expression and prognosis for patients with BM from LC. LC, lung cancer; BM, brain metastasis; TNM, tumor-node-metastasis; N, node; miR-330, microRNA-330; SE, standard error; Exp., exponential; df, degree of freedom

\begin{tabular}{lccccccc}
\hline Factor & B & SE & Wald & df & $P$ & Exp. (B) & 95.0\%CI for Exp. (B) \\
\hline Extracranial metastasis & 0.525 & 0.203 & 6.682 & 1 & 0.010 & 1.691 & $1.135 \sim 2.518$ \\
TNM stage & 0.144 & 0.138 & 4.746 & 1 & 0.029 & 1.155 & $1.015 \sim 1.315$ \\
N stage & 0.801 & 0.132 & 11.990 & 1 & 0.001 & 2.228 & $1.416 \sim 3.507$ \\
miR-330 & 0.706 & 0.198 & 14.519 & 1 & $<0.001$ & 2.027 & $1.409 \sim 2.915$ \\
\hline
\end{tabular}

Fig. 2. Kaplan-Meier survival curves for patients with BM from LC. (A) Kaplan-Meier survival curves for patients with LC who have high and low miR-330 expression levels; (B) Kaplan-Meier survival curves for patients with LC in the radiation-sensitive and radiation-resistant groups; (C) Kaplan-Meier survival curves for patients with LC who have high and low miR-330 expression levels in the resistant group; (D) Kaplan-Meier survival curves for patients with LC who have high and low miR-330 expression levels in the sensitive group; miR-330, microRNA-330; LC, lung cancer; BM, brain metastasis.
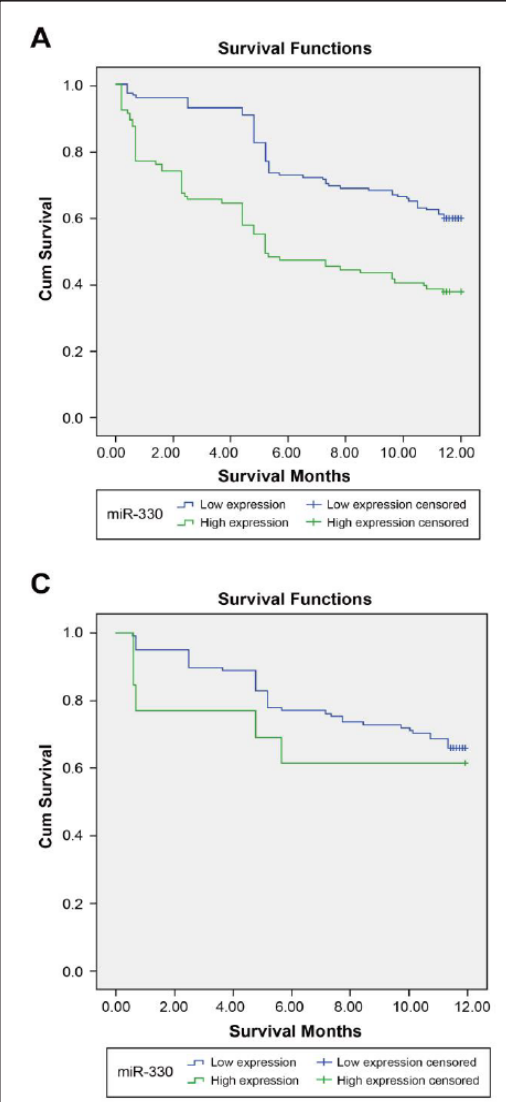

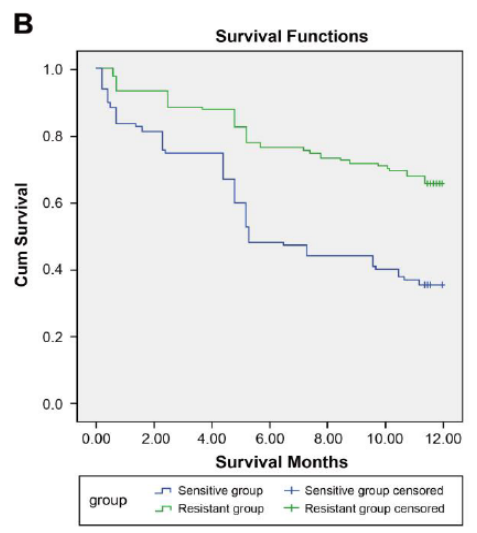

D

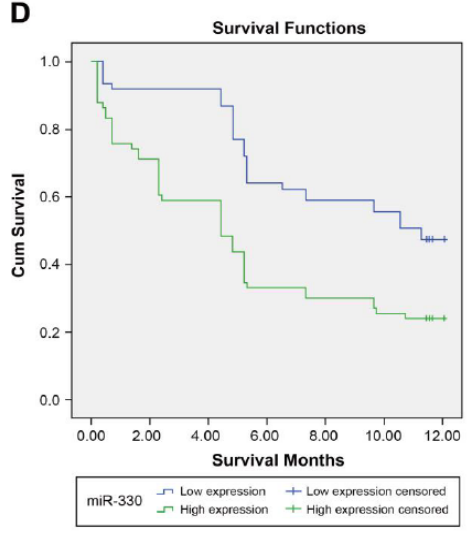

time was 9.5 months, which is significantly higher than the corresponding survival rates $(26.92 \%, 21.15 \%)$ and median survival time (6.6 months) of patients with high miR-330 expression. The corresponding survival rates and the median survival time in the radiationsensitive group were $77.09 \%, 69.47 \%$ and 9.7 months, which are significantly higher than those in the radiation-resistant group (47.24\%, 37.80\% and 7.2 months). In the radiationsensitive group, the patients with low miR-330 expression showed higher survival rates (85.59\% and $77.12 \%$ ) and a higher median survival time (9.7 months) than the patients with high miR-330 expression $(27.78 \%, 0 \%$ and 8.3 months). In the radiation-resistant group, the patients with low miR-330 expression showed higher survival rates $(88.89 \%$ and 


\section{Cellular Physiology Cell Physiol Biochem 2017;42:2220-2229

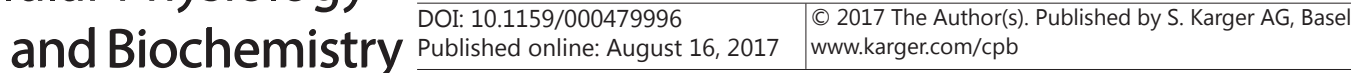

Jiang et al.: miR-330 and Radiation in Patients with BM from LC

$72.22 \%$ ) and a higher median survival time (8.7 months) to the patients with high miR-330 expression (60.44\%, 52.75\% and 5.4 months) (all $P<0.05$, Fig. 2).

Multivariate Analysis of Clinicopathological Features and miR-330 Expression and Prognosis for Patients with BM from $L C$

After quantitative assignment to extracranial metastasis, tumor diameter, TNM stage, $\mathrm{N}$ stage, and miR-330 expression, the COX model was established with $P<0.05$ as a significant standard for variables. The results of multivariate analysis demonstrated that extracranial metastasis, TNM stage, $\mathrm{N}$ stage and miR-330 expression were individual risk factors for the prognosis of patients with BM from LC (Table 6).

\section{Discussion}

Various researchers have identified miRNAs as potential biomarkers for the diagnosis, prognosis and prediction of the response to radiation therapy in tumorigenesis [30, 36, 37]. Promising roles of miRNA in carcinogenesis have been shown to be closely related to the epithelial-mesenchymal transition, cancer stem cell properties, tumor metastasis initiation and response to radiotherapy or chemotherapy [38]. The altered expression of miR-330 has been found in the carcinogenesis of various tumors $[39,40]$. The present study sought to investigate miR-330 expression in patients with BM from LC following conventional wholebrain radiation and the role of miR-330 in radiation sensitivity and prognosis. Our research provided evidence that miR-330 expression was downregulated in radiation-sensitive patients with BM from LC and was associated with a lower survival rate and median survival time. Therefore, miR-330 can function as a potential prognostic biomarker and predict radiation sensitivity in patients with BM from LC.

The findings of our study revealed that miR-330 exhibited lower expression in the radiation-sensitive group than in the radiation-resistant group. Current studies concerning miR-330 have mostly concentrated on its role in various cancer types by regulating Sp1, CDC42 and E2F1. MiR-330 can function as a tumor suppressor by inhibiting the translation of Sp1 and E2F1 in prostate cancer, and reduced E2F1 protein expression exerts a downstream effect of downregulating the levels of p-protein kinase B (Akt) and initiating pro-apoptotic pathways, while the downregulation of the Sp1 protein displays an anti-metastatic effect $[27,41]$. A previous study suggested that the E2F1/p-Akt pathway improves cell survival in response to cytotoxic insult caused by chemotherapeutics and radiation, and miR-330$3 p$ expression is inversely correlated with the expression of the E2F1 protein [42]. In colorectal cancer, it has also been reported that miR-330 can serve as a tumor suppressor by suppressing CDC42 translation and negatively regulating the proliferation of colorectal cancer cells [29]. Regarding miR-330, it remains unknown which strand of the miRNA duplex, miR-330-3p or miR-330-5p, performs as the functionally mature strand [26]. MiR-330-3p can control cell proliferation by targeting the early growth response 2 in NSCLC [4]. Indeed, miR-330-5p is also identified to be a credible binding site in the E2F1 mRNA sequence [43]. Yoo et al. reported that downregulated miR-330-5p expression can affect colorectal cancer development [40]. Bibby and colleagues observed an increase in radioresistance due to miR$330-5 p$ silencing, suggesting that the downregulation of miR-330-5p in tumors can alter the response to radiotherapy in esophageal adenocarcinoma [42], which is consistent with our results.

It was also found that at the $6^{\text {th }}$ month and the $1^{\text {st }}$ year after whole-brain radiation therapy, patients with low miR-330 expression displayed a lower survival rate and median survival time than patients with high miR-330 expression, indicating that the downregulation of miR-330 expression was associated with a lower survival rate and median survival time. MiRNAs are often found to be related to the survival and prognosis of patients with different cancers [44-47]. Zhang et al. demonstrated that miR-221 overexpression is correlated with poor prognosis in patients with NSCLC [48]. MiR-148b expression was also shown by Ge et 


\section{Cellular Physiology Cell Physiol Biochem 2017;42:2220-2229 \begin{tabular}{l|l|l} 
and Biochemistry Published onlIne: August 16, 2017 & $\begin{array}{l}\text { C) } 2017 \text { The Author(s). Published by S. Karger AG, Basel } \\
\text { www.karger.com/cpb }\end{array}$ \\
\hline
\end{tabular}}

al. to be independently related to the overall survival of patients with NSCLC [49]. Kim et al. also indicate that the expressions of miR-200c and miR-126 are associated with prognosis in patients with NSCLC [50]. Deng et al clarified the metastatic-inhibitory effect of miR-193a$3 p$ on LC cells by deregulating the expression of tumor-related proteins [9]. It is safe for us to speculate on the prognostic value of miR-330 as a suppressor in cancers. Furthermore, miR330 was correlated with extracranial metastasis, maximum BM diameter, TNM stage and $\mathrm{N}$ stage. Logistic regression and Cox regression analyses revealed that extracranial metastasis, TNM stage, $\mathrm{N}$ stage and miR-330 expression were factors that influence radiation sensitivity and were individual prognostic factors for patients with BM from LC. MiRNA-200c and ETAR mRNA expressions have been revealed to be associated with TNM stage and N stage in patients with advanced NSCLC [51]. Additionally, miR-197 and miR-184 are reported to be correlated with BM from LC $[52,53]$.

To conclude, our data revealed that miR-330 was expressed at low levels in radiationsensitive patients with BM from $\mathrm{LC}$ and was associated with a lower survival rate and a median survival time. These results suggested that the downregulation of miR-330 expression was sensitive to radiation therapy and correlated with a poor prognosis in patients with BM from LC. Therefore, miR-330 may represent a novel predictor for radiation sensitivity and a therapeutic target for the prognosis of patients with BM from LC. Further studies based on different radiation doses for the patients with BM from LC will be carried out in the future to confirm and develop our conclusions.

\section{Acknowledgments}

We would like to thank all contributors to this article.

\section{Disclosure Statement}

The authors declare no conflict of interest.

\section{References}

1 Huang Q Ouyang X: Predictive biochemical-markers for the development of brain metastases from lung cancer: clinical evidence and future directions. Cancer Epidemiol 2013;37:703-707.

- Blum TG, Rich A, Baldwin D, Beckett P, De Ruysscher D, Faivre-Finn C, Gaga M, Gamarra F, Grigoriu B, Hansen NC, Hubbard R, Huber RM, Jakobsen E, Jovanovic D, Konsoulova A, Kollmeier J, Massard G, McPhelim J, Meert AP, Milroy R, Paesmans M, Peake M, Putora PM, Scherpereel A, Schonfeld N, Sitter H, Skaug K, Spiro S, Strand TE, Taright S, Thomas M, van Schil PE, Vansteenkiste JF, Wiewrodt R, Sculier JP: The European initiative for quality management in lung cancer care. Eur Respir J 2014;43:1254-1277.

3 Jemal A, Siegel R, Xu J, Ward E: Cancer statistics, 2010. CA Cancer J Clin 2010;60:277-300.

-4 Liu X, Shi H, Liu B, Li J, Liu Y, Yu B: miR-330-3p controls cell proliferation by targeting early growth response 2 in non-small-cell lung cancer. Acta Biochim Biophys Sin (Shanghai) 2015;47:431-440.

-5 Pollom EL, Qian Y, Durkee BY, von Eyben R, Maxim PG, Shultz DB, Gensheimer M, Diehn M, Loo BW, Jr:: Hypofractionated Intensity-Modulated Radiotherapy for Patients With Non-Small-Cell Lung Cancer. Clin Lung Cancer 2016;17:588-594.

6 Berriochoa C, Videtic GM, Woody NM, Djemil T, Zhuang T, Stephans KL: Stereotactic Body Radiotherapy for T3N0 Lung Cancer With Chest Wall Invasion. Clin Lung Cancer 2016;17:595-601.

7 Loganadane G, Martinetti F, Mercier O, Krhili S, Riet FG, Mbagui R, To H, Le Pechoux C, Levy A: Stereotactic ablative radiotherapy for early stage non-small cell lung cancer: A critical literature review of predictive factors of relapse. Cancer Treat Rev 2016;50:240-246.

-8 You S, Li R, Park D, Xie M, Sica GL, Cao Y, Xiao ZQ Deng X: Disruption of STAT3 by niclosamide reverses radioresistance of human lung cancer. Mol Cancer Ther 2014;13:606-616.

-9 Deng W, Yan M, Yu T, Ge H, Lin H, Li J, Liu Y, Geng Q, Zhu M, Liu L, He X, Yao M: Quantitative proteomic analysis of the metastasis-inhibitory mechanism of miR-193a-3p in non-small cell lung cancer. Cell Physiol Biochem 2015;35:1677-1688.

10 He Z, Xia Y, Pan C, Ma T, Liu B, Wang J, Chen L, Chen Y: Up-Regulation of MiR-452 Inhibits Metastasis of Non- 


\section{Cellular Physiology Cell Physiol Biochem 2017;42:2220-2229 \begin{tabular}{l|l|l} 
and Biochemistry Published onIIne: August 16, 2017 & $\begin{array}{l}\text { C) } 2017 \text { The Author(s). Published by S. Karger AG, Basel } \\
\text { www.karger.com/cpb }\end{array}$
\end{tabular}}

Jiang et al.: miR-330 and Radiation in Patients with BM from LC

Small Cell Lung Cancer by Regulating BMI1. Cell Physiol Biochem 2015;37:387-398.

11 Zhao N, Wilkerson MD, Shah U, Yin X, Wang A, Hayward MC, Roberts P, Lee CB, Parsons AM, Thorne LB, Haithcock BE, Grilley-Olson JE, Stinchcombe TE, Funkhouser WK, Wong KK, Sharpless NE, Hayes DN: Alterations of LKB1 and KRAS and risk of brain metastasis: comprehensive characterization by mutation analysis, copy number, and gene expression in non-small-cell lung carcinoma. Lung Cancer 2014;86:255261.

12 Iuchi T, Shingyoji M, Itakura M, Yokoi S, Moriya Y, Tamura H, Yoshida Y, Ashinuma H, Kawasaki K, Hasegawa Y, Sakaida T, Iizasa T: Frequency of brain metastases in non-small-cell lung cancer, and their association with epidermal growth factor receptor mutations. Int J Clin Oncol 2015;20:674-679.

-13 Arora S, Ranade AR, Tran NL, Nasser S, Sridhar S, Korn RL, Ross JT, Dhruv H, Foss KM, Sibenaller Z, Ryken T, Gotway MB, Kim S, Weiss GJ: MicroRNA-328 is associated with (non-small) cell lung cancer (NSCLC) brain metastasis and mediates NSCLC migration. Int J Cancer 2011;129:2621-2631.

-14 Eichler AF, Kahle KT, Wang DL, Joshi VA, Willers H, Engelman JA, Lynch TJ, Sequist LV: EGFR mutation status and survival after diagnosis of brain metastasis in nonsmall cell lung cancer. Neuro Oncol 2010;12:11931199.

15 Wang X, Jiao W, Zhao Y, Zhang L, Yao R, Wang Y, Wang M, Luo Y, Zhao J: CUG-binding protein 1 (CUGBP1) expression and prognosis of brain metastases from non-small cell lung cancer. Thorac Cancer 2016;7:3238.

16 Tutar Y, Ozgur A, Tutar E, Tutar L, Pulliero A, Izzotti A: Regulation of oncogenic genes by MicroRNAs and pseudogenes in human lung cancer. Biomed Pharmacother 2016;83:1182-1190.

17 Flynt AS, Lai EC: Biological principles of microRNA-mediated regulation: shared themes amid diversity. Nat Rev Genet 2008;9:831-842.

18 Shi M, Xie D, Gaod Y, Xie K: Targeting miRNAs for pancreatic cancer therapy. Curr Pharm Des 2014;20:5279-5286.

19 Yang S, Zhang Y, Zhao X, Wang J, Shang J: microRNA-361 targets Wilms' tumor 1 to inhibit the growth, migration and invasion of non-small-cell lung cancer cells. Mol Med Rep 2016;10.3892/mmr.2016.5858

20 Afgar A, Fard-Esfahani P, Mehrtash A, Azadmanesh K, Khodarahmi F, Ghadir M, Teimoori-Toolabi L: MiR-339 and especially miR-766 reactivate the expression of tumor suppressor genes in colorectal cancer cell lines through DNA methyltransferase 3B gene inhibition. Cancer Biol Ther 2016;10.1080/15384047.2016.12356571-13.

21 Guo Z, Zhao C, Wang Z: MicroRNAs as ideal biomarkers for the diagnosis of lung cancer. Tumour Biol 2014;35:10395-10407.

22 Cortinovis D, Monica V, Pietrantonio F, Ceresoli GL, La Spina CM, Wannesson L: MicroRNAs in non-small cell lung cancer: current status and future therapeutic promises. Curr Pharm Des 2014;20:3982-3990.

23 Li J, Yu T, Cao J, Liu L, Liu Y, Kong HW, Zhu MX, Lin HC, Chu DD, Yao M, Yan MX: MicroRNA-148a Suppresses Invasion and Metastasis of Human Non-Small-Cell Lung Cancer. Cell Physiol Biochem 2015;37:1847-1856.

-24 Zhu X, Fu C, Zhang L, Xu G, Wang S: MiRNAs associated polymorphisms in the 3'UTR of MET promote the risk of non-small cell lung cancer. Cell Physiol Biochem 2015;37:1159-1167.

25 Yan A, Yang C, Chen Z, Li C, Cai L: MiR-761 Promotes Progression and Metastasis of Non-Small Cell Lung Cancer by Targeting ING4 and TIMP2. Cell Physiol Biochem 2015;37:55-66.

-26 Griffiths-Jones S: miRBase: microRNA sequences and annotation. Curr Protoc Bioinformatics 2010;Chapter 12:Unit 12 19 11-10.

27 Lee KH, Chen YL, Yeh SD, Hsiao M, Lin JT, Goan YG, Lu PJ: MicroRNA-330 acts as tumor suppressor and induces apoptosis of prostate cancer cells through E2F1-mediated suppression of Akt phosphorylation. Oncogene 2009;28:3360-3370.

-28 Pang Y, Young CY, Yuan H: MicroRNAs and prostate cancer. Acta Biochim Biophys Sin (Shanghai) 2010;42:363-369.

29 Li Y, Zhu X, Xu W, Wang D, Yan J: miR-330 regulates the proliferation of colorectal cancer cells by targeting Cdc42. Biochem Biophys Res Commun 2013;431:560-565.

-30 Chen X, Xu Y, Liao X, Liao R, Zhang L, Niu K, Li T, Li D, Chen Z, Duan Y, Sun J: Plasma miRNAs in predicting radiosensitivity in non-small cell lung cancer. Tumour Biol 2016;37:11927-11936.

-31 Si X, Zhang X, Hao X, Li Y, Chen Z, Ding Y, Shi H, Bai J, Gao Y, Cheng T, Yang FC, Zhou Y: Upregulation of miR99a is associated with poor prognosis of acute myeloid leukemia and promotes myeloid leukemia cell expansion. Oncotarget 2016;10.18632/oncotarget.12947 


\section{Cellular Physiology Cell Physiol Biochem 2017;42:2220-2229

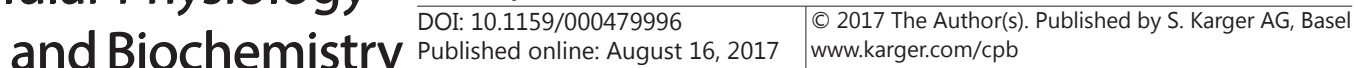

32 Martin RC, Gerstenecker A, Nabors LB, Marson DC, Triebel KL: Impairment of medical decisional capacity in relation to Karnofsky Performance Status in adults with malignant brain tumor. Neurooncol Pract 2015;2:13-19.

33 Lu Y, Fan Y: Combined action of EGFR tyrosine kinase inhibitors and whole-brain radiotherapy on EGFRmutated non-small-cell lung cancer patients with brain metastasis. Onco Targets Ther 2016;9:1135-1143.

34 Bonanno L, Zago G, Marulli G, Del Bianco P, Schiavon M, Pasello G, Polo V, Canova F, Tonetto F, Loreggian L, Rea F, Conte P, Favaretto A: Radiological response and survival in locally advanced non-small-cell lung cancer patients treated with three-drug induction chemotherapy followed by radical local treatment. Onco Targets Ther 2016;9:3671-3681.

-35 Rao X, Huang X, Zhou Z, Lin X: An improvement of the $2^{\wedge}$ (-delta delta CT) method for quantitative realtime polymerase chain reaction data analysis. Biostat Bioinforma Biomath 2013;3:71-85.

-36 Szajnik M, Czystowska-Kuzmicz M, Elishaev E, Whiteside TL: Biological markers of prognosis, response to therapy and outcome in ovarian carcinoma. Expert Rev Mol Diagn 2016;16:811-826.

-37 Madhavan D, Cuk K, Burwinkel B, Yang R: Cancer diagnosis and prognosis decoded by blood-based circulating microRNA signatures. Front Genet 2013;4:116.

38 Zhao L, Bode AM, Cao Y, Dong Z: Regulatory mechanisms and clinical perspectives of miRNA in tumor radiosensitivity. Carcinogenesis 2012;33:2220-2227.

-39 Yao Y, Xue Y, Ma J, Shang C, Wang P, Liu L, Liu W, Li Z, Qu S, Li Z, Liu Y: MiR-330-mediated regulation of SH3GL2 expression enhances malignant behaviors of glioblastoma stem cells by activating ERK and PI3K/ AKT signaling pathways. PLoS One 2014;9:e95060.

40 Yoo HI, Kim BK, Yoon SK: MicroRNA-330-5p negatively regulates ITGA5 expression in human colorectal cancer. Oncol Rep 2016;36:3023-3029.

41 Mao Y, Chen H, Lin Y, Xu X, Hu Z, Zhu Y, Wu J, Xu X, Zheng X, Xie L: microRNA-330 inhibits cell motility by downregulating Sp1 in prostate cancer cells. Oncol Rep 2013;30:327-333.

42 Bibby BA, Reynolds JV, Maher SG: MicroRNA-330-5p as a Putative Modulator of Neoadjuvant Chemoradiotherapy Sensitivity in Oesophageal Adenocarcinoma. PLoS One 2015;10:e0134180.

43 Betel D, Wilson M, Gabow A, Marks DS, Sander C: The microRNA.org resource: targets and expression. Nucleic Acids Res 2008;36:D149-153.

44 Suto T, Yokobori T, Yajima R, Morita H, Fujii T, Yamaguchi S, Altan B, Tsutsumi S, Asao T, Kuwano H: MicroRNA-7 expression in colorectal cancer is associated with poor prognosis and regulates cetuximab sensitivity via EGFR regulation. Carcinogenesis 2015;36:338-345.

45 Wang Q, Qin J, Chen A, Zhou J, Liu J, Cheng J, Qiu J, Zhang J: Downregulation of microRNA-145 is associated with aggressive progression and poor prognosis in human cervical cancer. Tumour Biol 2015;36:37033708.

46 Peng DX, Luo M, Qiu LW, He YL, Wang XF: Prognostic implications of microRNA-100 and its functional roles in human epithelial ovarian cancer. Oncol Rep 2012;27:1238-1244.

47 Hudson RS, Yi M, Esposito D, Watkins SK, Hurwitz AA, Yfantis HG, Lee DH, Borin JF, Naslund MJ, Alexander RB, Dorsey TH, Stephens RM, Croce CM, Ambs S: MicroRNA-1 is a candidate tumor suppressor and prognostic marker in human prostate cancer. Nucleic Acids Res 2012;40:3689-3703.

-48 Zhang Y, Zhao Y, Sun S, Liu Z, Zhang Y, Jiao S: Overexpression of MicroRNA-221 is associated with poor prognosis in non-small cell lung cancer patients. Tumour Biol 2016;37:10155-10160.

49 Ge H, Li B, Hu WX, Li RJ, Jin H, Gao MM, Ding CM: MicroRNA-148b is down-regulated in non-small cell lung cancer and associated with poor survival. Int J Clin Exp Pathol 2015;8:800-805.

-50 Kim MK, Jung SB, Kim JS, Roh MS, Lee JH, Lee EH, Lee HW: Expression of microRNA miR-126 and miR-200c is associated with prognosis in patients with non-small cell lung cancer. Virchows Arch 2014;465:463-471.

51 Zhao J, Zhao Y, Wang Z, Xuan Y, Luo Y, Jiao W: Loss expression of micro ribonucleic acid (miRNA)-200c induces adverse post-surgical prognosis of advanced stage non-small cell lung carcinoma and its potential relationship with ETAR messenger RNA. Thorac Cancer 2015;6:421-426.

52 Remon J, Alvarez-Berdugo D, Majem M, Moran T, Reguart N, Lianes P: miRNA-197 and miRNA-184 are associated with brain metastasis in EGFR-mutant lung cancers. Clin Transl Oncol 2016;18:153-159.

53 Kitano K, Watanabe K, Emoto N, Kage H, Hamano E, Nagase T, Sano A, Murakawa T, Nakajima J, Goto A, Fukayama M, Yatomi Y, Ohishi N, Takai D: CpG island methylation of microRNAs is associated with tumor size and recurrence of non-small-cell lung cancer. Cancer Sci 2011;102:2126-2131. 